\title{
Ordering Size Optimization of Raw Material to Minimize Inventory Costs using Wagner-Within Algorithm and Silver-Meal Methods
}

\author{
Dira Ernawati ${ }^{*}$, Sinta Dewi ${ }^{1}$, Ni Ketut Sari $^{2}$ and Kurniawan Budianto ${ }^{1}$ \\ ${ }^{1}$ Industrial Engineering, Faculty Engineering, University of Pembangunan Nasional "Veteran" Jawa Timur, Indonesia \\ ${ }^{2}$ Chemical Engineering, Faculty Engineering, University of Pembangunan Nasional "Veteran" Jawa Timur, Indonesia
}

\begin{abstract}
Inventory is one of the current assets that can be classified as company assets. But in reality, inventory often turns into an operational problem that can affect the company's overall performance. This problem occurs due to the incorrect determination of the amount of inventory. Both excess and shortage of inventory can lead to cost overruns. This study applies the Wagner Whitin Algorithm and the Silver-Meal method in the lot-sizing process and the ABC (Always Better Control) method in determining the classification of raw materials at PT. X. Using the ABC method, it is known that the ADC-12 Ingot item has a very significant effect to inventory. Inventory optimization using the Wagner Whitin Algorithm and the Silver-Meal method resulted in the optimal frequency of ordering ADC-12 Ingots is 9 times and the total inventory cost is $994,098,000$ IDR as well as inventory cost savings of around $18,403,180$ IDR or $1.8 \%$ of the cost of existing inventory.
\end{abstract}

Keyword : Inventory Costs, Wagner-Within Algorithm, Silver-Meal Methods

\section{Introduction}

Inventory is one of the current assets that can be classified as company assets. But in reality, inventory often turns into an operational problem that can affect the company's overall performance. Lack of inventory can disrupt the production process and make inventory costs increase due to emergency procurement costs. Meanwhile, excess inventory can lead to excessively high storage and maintenance costs.

PT. XYZ is one of the subcontracting companies of automotive parts manufacturers. As a subcontracting company, PT. XYZ is very concerned about inventory issues that will affect the demand fulfillment which is one of the criteria required in partnership.

The company has no problems in meeting the demands of its business partners. However, the company feels the need to optimize raw material control. Based on observations in the company, it is known that in placing orders PT XYZ only consider the numbers of raw materials that can meet the needs for a certain period without considering the inventory costs incurred. This can lead to a buildup of raw materials and an increase in inventory costs.

This study applies the Wagner Whitin Algorithm and the Silver-Meal method in the lot-sizing process and the ABC (Always Better Control) method in determining the classification of PT XYZ raw materials. This study is willing to provide the right solution to $\mathrm{PT} X Y Z$ problems in determining the optimal order size of raw material procurement to minimize inventory cost.

\section{Literature Review}

Inventory management is the ability of a company to organize and manage its inventory to ensure availability both in stable and fluctuating market conditions. The types of inventory i.e office supplies inventory, raw materials inventory, work in process inventory, and inventory of finished goods. The goal of inventory management is to provide the right amount of material, the right lead time at a low cost. Thus, the right inventory level and the right ordering system are very important in saving the company's expenses and at the same time increasing the company's profits.

In this section, the method used in this study will be explained, which consists of the ABC method, the Wagner-Within Algorithm, and the Silver-Meal Algorithm.

\subsection{ABC Method}

The $\mathrm{ABC}$ method aims to classify all the inventory items into three categories based on their usage value [1]. Inventories with a high usage value (about $70 \%-80 \%$ or more) of the total inventory value with only $5-10 \%$ of

\footnotetext{
* Corresponding author : diraernawati@gmail.com
} 
the total items are classified in class A. Class B is a group of items with moderate usage value of inventory which includes $15 \%-25 \%$ of the total inventory value and $10-20 \%$ of the total items. The last is inventory which has low usage values $(5 \%-10 \%$ of the total value of inventory) which consists of $70-80 \%$ of the total items that will be classified into class C. However, this proportion is not absolute because variations in prices and levels of use as well as management policies often lead to variations in the proportion, although it is still around this value.

According to Gaspersz [2] the procedure used to classify inventory into $\mathrm{A}, \mathrm{B}, \mathrm{C}$, is as follows:

1. Determine inventory usage per item over a certain period

2. Calculate the total usage value of each item of inventory

3. Calculating the total usage value of inventory

4. Calculate the percentage of usage value of each item

5. Sort the percentage of usage values from the largest to the smallest

6. Classify items into categories A, B, or C

\subsection{Wagner Whitin Algorithm}

The Wagner Whitin algorithm is the optimum solution to the dynamic deterministic order size problem, where the requirements for each period must be met. The goal is to obtain an optimal ordering strategy for the entire demand schedule by minimizing total procurement costs and cost savings. This algorithm was developed by Wagner and Within in 1958 [3]. A problem is categorized as dynamic deterministic if the level of demand/need is known with certainty but the size varies from period to period. This algorithm calculates all possible ordering alternatives in meeting the demand for each period in the planning horizon so that it always gives the optimal answer. Kulkarni n Rajhans [1] compared several methods i.e Lot for Lot, Economic order Quantity, Period order quantity, Least unit cost, Least total cost, Least period cost, Wagner-Whitin Algorithm to find minimal inventory cost, and in all cases, the Wagner-Whitin model gives the minimum total annual inventory cost [4].

There are five steps in the Wagner-Whitin Algorithm:

1. Calculating Cumulative demand from the beginning of the period to the end of the period using formula (1).

$$
Q_{c: e}=Q_{c: i}+Q_{e}
$$

where $Q_{c: e}$ is the total number of demand for the entire period, $Q_{c: i}$ is the total number of demand from all previous periods, and $Q_{e}$ is the number of demand in the intended period.

2. Calculating the total variable costs for all possible ordering alternatives in $\mathrm{N}$ periods. The total variable costs in period $\mathrm{c}$ to period e which consist of ordering costs and holding costs are represented as $\mathrm{Z}$ (formula 2 ).

$$
\mathrm{Z}_{\mathrm{c}: \mathrm{e}}=\mathrm{C}+\mathrm{hP} \sum_{\mathrm{i}=\mathrm{c}}^{\mathrm{e}}\left(\mathrm{Q}_{\mathrm{c}: \mathrm{e}}-\mathrm{Q}_{\mathrm{c}: \mathrm{i}}\right)
$$

C : ordering cost per order placement

$\mathrm{h}$ : holding cost per unit per period

$\mathrm{P}$ : unit price per item

$\mathrm{Q}_{\mathrm{c}: \mathrm{e}}$ : total number of demand for the entire targeted period $=\sum_{\mathrm{i}=\mathrm{e}}^{\mathrm{e}} \mathrm{R}_{\mathrm{ki}}$

$\mathrm{R}_{\mathrm{ki}}$ : demand in $\mathrm{k}^{\text {th }}$ period

$\mathrm{Q}_{\mathrm{c}: \mathrm{i}}:$ demand in i period

3. Calculate the order combination that can minimize the cost, described by $f_{e}$ as minimum cost at e period, the inventory level at the end of period e is zero. The step begins with $f_{0}=0$ then calculating $f_{1}, f_{2}, \ldots \ldots f_{N}$ in those order combinations. Then calculating $f_{e}$ using formula:

$$
f_{e}=\operatorname{Min}\left(Z_{c: e}+f_{c-1}\right) \text { for } c=1.2 \ldots e
$$

4. Define the optimal solution

\subsection{Silver-Meal Algorithm}

The Silver-Meal method was developed by Edward Silver and Harlan Meal based on the cost period [3]. Silver-Meal Algorithm is a heuristic approach to determine the purchase lot size which is relatively easy to use $[5,6]$. The silver meal heuristic approach is similar to the EOQ approach, but in the calculation, it is based more on the variable cost of the purchasing period and not based on the total demand during the planning horizon $[7,8]$.

The steps of the Silver-Meal algorithm based on Asmal et all [3] are:

1. Calculating the average cost of inventory using formula (4).

$$
\frac{T V C(T)}{T}=\frac{C+P h \sum_{k=1}^{T}(k-1) D_{k}}{T}
$$

$$
\text { Where: }
$$

C : ordering cost per order placement

$\mathrm{h}$ : holding cost per unit per period

$\mathrm{P}$ : unit price per item

$\mathrm{T}:$ number of period

$D_{\mathrm{k}}$ : demand in k period

This step is carried out in period 1 until the period that has the lowest average inventory cost is found. This period is the order period and the amount of orders is the total demand during that period.

2. Repeat step 1 until all have been evaluated and a procurement table is compiled

\section{Methodology}

This section will explain the calculation phase and the steps taken to get the order frequency and order size that can optimize the inventory costs of PT XYZ.

\subsection{Raw Material Classification}

Based on field data collection and observation, it is known that raw materials at PT XYZ are consist of Ingot ADC-12, Honda Metal Sleeper (MS), Yamaha MS, Vario MS, and Suzuki MS. The unit price of each item and the amount of usage or demand 
within three months can be seen in Table 1. Using the data in Table 1, calculations are then carried out using the $\mathrm{ABC}$ method according to the procedure used in Gaspersz [2]. The results of the classification of raw materials are obtained in Table 1.

Ingot $\mathrm{ADC}-12 \mathrm{~s}$ are in category $\mathrm{A}$ because they have a large percentage in fund absorptions, about $94.92 \%$, with a small percentage of item types, which is only $20 \%$ of all items. Then for Honda MS, Suzuki MS, Yamaha MS, and Vario MS are classified as category $\mathrm{C}$ because the percentage of fund absorptions is very small, which is only $5 \%$ (combined) of the total fund absorptions with a large percentage of item types, which is $80 \%$. Thus category $\mathrm{A}$ is a category of raw materials that has a very significant influence on the total cost of inventory. So, to optimize PT XYZ's inventory costs, it will focus only on optimizing the inventory of Ingot ADC-12.

Table 1. Demand and Raw Material Classification

\begin{tabular}{|c|c|c|c|c|}
\hline Items Type & Units & Demand & $\begin{array}{l}\text { Units } \\
\text { Price } \\
\text { (IDR) }\end{array}$ & $\begin{array}{l}\text { Total } \\
\text { Price } \\
\text { (1000 } \\
\text { IDR) }\end{array}$ \\
\hline $\begin{array}{l}\text { Ingot ADC- } \\
12\end{array}$ & $\mathrm{Kg}$ & 24.7596 & 26.000 & 6.437 .496 \\
\hline Honda MS & Unit & 3.213 .900 & 100 & 321.390 \\
\hline Suzuki MS & Unit & 85.000 & 110 & 9.350 \\
\hline Yamaha MS & Unit & 70.000 & 110 & 7.700 \\
\hline Vario MS & Unit & 40.000 & 150 & 6.000 \\
\hline Total & & & & 6.781 .936 \\
\hline Items Type & $\begin{array}{r}\text { Perce } \\
F \\
\text { Abs }\end{array}$ & $\begin{array}{l}\text { gge of } \\
\text { d } \\
\text { tion }\end{array}$ & $\begin{array}{l}\text { Percentage } \\
\text { of Item } \\
\text { Type }\end{array}$ & $\begin{array}{c}\text { Item } \\
\text { Category }\end{array}$ \\
\hline $\begin{array}{l}\text { Ingot ADC- } \\
12\end{array}$ & & & $20 \%$ & A \\
\hline Honda MS & & & \multirow{4}{*}{$80 \%$} & \multirow{4}{*}{$\mathrm{C}$} \\
\hline Suzuki MS & & & & \\
\hline Yamaha MS & \multicolumn{2}{|c|}{$0,11 \%$} & & \\
\hline Vario MS & \multicolumn{2}{|c|}{$0,09 \%$} & & \\
\hline Total & \multicolumn{2}{|c|}{$100 \%$} & $100 \%$ & \\
\hline
\end{tabular}

\subsection{Existing Total Cost of Inventory Calculation}

There are two basic variable costs in inventory, namely ordering costs and holding costs. Based on observations, the details of ordering cost components and storage cost components at PT XYZ are presented in Table 2.

Tabel 2. Ordering Cost Components and Holding Cost Components of Ingot ADC-12

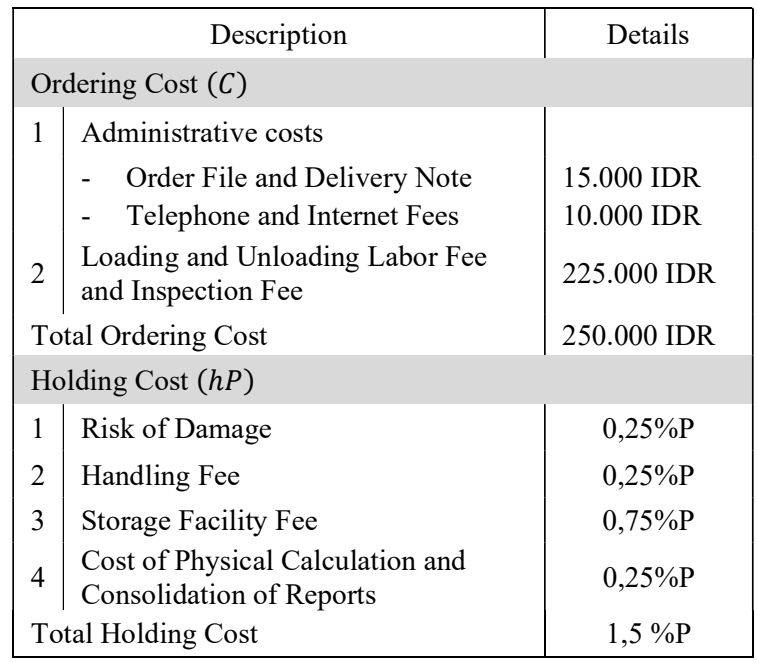

Where the value of "P" in the holding cost component is the unit price of Ingot ADC-12 item, which is 26,000 IDR.

In the existing condition, the procurement of the Ingots $\mathrm{ADC}$ 12 is carried out once a month at the beginning of the month to meet the demand for that month. The calculation of the inventory cost of Ingots ADC-12 from October to December 2018 can be seen in Table 3 .

From Table 3 it can be seen that the existing total cost of inventory that must be incurred by PT XYZ for Ingots ADC12 from October to December 2018 is $1,012,501,180$ IDR, with a variable cost of $20,731,180$ IDR.

Tabel 3. Total Existing Inventory Cost of Ingot ADC-12

\begin{tabular}{|c|c|c|c|c|c|c|c|}
\hline Week & $\begin{array}{c}\text { Receipt } \\
(\mathrm{Kg})\end{array}$ & $\begin{array}{c}\text { Demand } \\
(\mathrm{Kg})\end{array}$ & $\begin{array}{c}\text { Leftovers } \\
(\mathrm{Kg})\end{array}$ & $\begin{array}{c}\text { Ordering } \\
\text { Cost }(\mathrm{Rp})\end{array}$ & $\begin{array}{c}\text { Holding Cost } \\
(\mathrm{Rp})\end{array}$ & $\begin{array}{c}\text { Purchasing } \\
\text { Cost }(\mathrm{Rp})\end{array}$ & $\begin{array}{c}\text { Total Cost } \\
(\mathrm{Rp})\end{array}$ \\
W-1 Oct & 13.480 & 3.900 & 9.580 & 250.000 & 3.736 .200 & 350.480 .000 & 354.466 .200 \\
W-2 Oct & & 650 & 8.930 & 0 & 3.482 .700 & 0 & 3.482 .700 \\
W-3 Oct & & 0 & 8.930 & 0 & 3.482 .700 & 0 & 3.482 .700 \\
W-4 Oct & & 8.930 & 0 & 0 & 0 & 0 & 0 \\
W-1 Nov & 10.303 & 3.130 & 7.173 & 250.000 & 2.797 .000 & 267.878 .000 & 270.925 .470 \\
W-2 Nov & & 4.173 & 3.000 & 0 & 1.170 .000 & 0 & 1.170 .000 \\
W-3 Nov & & 3.000 & 0 & 0 & 0 & 0 & 0 \\
W-4 Nov & & 0 & 0 & 0 & 0 & 0 \\
W-1 Dec & 14.362 & 4.500 & 9.862 & 250.000 & 3.846 .180 & 373.412 .000 & 377.508 .180 \\
W-2 Dec & & 6302 & 3560 & 0 & 1.388 .400 & 0 & 1.388 .400 \\
W-3 Dec & & 3360 & 200 & 0 & 78.000 & 0 & 78.000 \\
W-4 Dec & & 200 & 0 & 0 & 0 & 0
\end{tabular}




\begin{tabular}{|c|c|c|c|c|} 
Total & 750.000 & 19.981 .180 & 991.770 .000 & 1.012 .501 .650 \\
\hline Variable Cost of Inventory & 20.731 .180 & & \\
\hline
\end{tabular}

\subsection{Determination of Order Size using The Wagner Within Algorithm}

Using formula number 2, the total variable costs can be calculated for all alternative orders that may occur in $\mathrm{N}$ periods and the results are shown in Table 4.

Table 4. Calculation of variable cost (Zce) Ingot $\mathrm{ADC}-12$ (in $1000 \mathrm{IDR}$ )

\begin{tabular}{|c|c|c|c|c|c|c|}
\hline & 1 & 2 & 3 & 4 & 5 & 6 \\
\hline 1 & 250 & 504 & 504 & 10.952 & 15.834 & 23.972 \\
\hline 2 & & 250 & 250 & 7.215 & 10.878 & 17.387 \\
\hline 3 & & & 250 & 3.733 & 6.174 & 11.057 \\
\hline 4 & & & & 250 & 1.471 & 4.726 \\
\hline 5 & & & & & 250 & 1.877 \\
\hline 6 & & & & & & 250 \\
\hline
\end{tabular}

\begin{tabular}{|c|c|c|r|r|r|r|}
\hline \multirow{2}{*}{$\mathrm{e}$} & 7 & 8 & 9 & 10 & 11 & 12 \\
\cline { 2 - 7 } 1 & & & & & & \\
\cline { 2 - 7 } & 30.99 & 30.99 & 45.03 & 67.15 & 80.25 & 81.11 \\
2 & 23.23 & 23.23 & 45.03 & 55.18 & 66 & 4 \\
\hline & 15.73 & 15.73 & 26.26 & 43.47 & 53.95 & 54.65 \\
3 & 7 & 7 & 7 & 1 & 4 & 6 \\
\hline & & & 17.01 & 31.75 & 40.93 & 41.55 \\
4 & 8.236 & 8.236 & 1 & 7 & 0 & 4 \\
\hline 5 & 4.217 & 4.217 & 7 & 6 & 9 & 5 \\
\hline & & & & 16.51 & 23.06 & 23.53 \\
6 & 1.420 & 1.420 & 6.685 & 6 & 8 & 6 \\
\hline 7 & 250 & 250 & 3.760 & 3 & 5 & 5 \\
\hline 8 & & & & & 10.85 & 11.16 \\
& & 250 & 2.005 & 6.921 & 2 & 4 \\
\hline 9 & & & 250 & 2.708 & 5.329 & 5.563 \\
\hline 10 & & & & 250 & 1.560 & 1.716 \\
\hline 11 & & & & & 250 & 328 \\
\hline 12 & & & & & & 250 \\
\hline
\end{tabular}

From the results of the Zce calculation in Table 4, then the combinations of orders that can minimize costs $\left(f_{e}\right)$ are calculated with formula number 3 , and the results are summarized in Table 5.
Tabel 5 Calculation of order combinations with minimum costs $\left(f_{e}\right)$ of Ingot ADC-12 (in 1000 IDR)

\begin{tabular}{|c|c|c|c|c|c|c|c|}
\hline e & 0 & 1 & 2 & 3 & 4 & 5 & 6 \\
\hline 1 & & $\begin{array}{r}25 \\
0\end{array}$ & $\begin{array}{r}50 \\
4\end{array}$ & $\begin{array}{r}50 \\
4\end{array}$ & $\begin{array}{r}10.95 \\
2\end{array}$ & $\begin{array}{r}15.83 \\
4\end{array}$ & $\begin{array}{r}23.97 \\
2\end{array}$ \\
\hline 2 & & & $\begin{array}{r}50 \\
0\end{array}$ & $\begin{array}{r}50 \\
0\end{array}$ & 7.465 & $\begin{array}{r}11.12 \\
8\end{array}$ & $\begin{array}{r}17.63 \\
7\end{array}$ \\
\hline 3 & & & & $\begin{array}{r}75 \\
0\end{array}$ & 4.233 & 6.674 & $\begin{array}{r}11.55 \\
7\end{array}$ \\
\hline 4 & & & & & 750 & 1.971 & 5.226 \\
\hline 5 & & & & & & 1.000 & 2.627 \\
\hline 6 & & & & & & & 1.250 \\
\hline$f_{e}$ & 0 & $\begin{array}{r}25 \\
0 \\
\end{array}$ & $\begin{array}{r}50 \\
0 \\
\end{array}$ & $\begin{array}{r}50 \\
0 \\
\end{array}$ & 750 & 1.000 & 1.250 \\
\hline
\end{tabular}

\begin{tabular}{|c|c|c|c|c|c|c|}
\hline & 7 & 8 & 9 & 10 & 11 & 12 \\
\hline & 30.99 & 30.99 & 45.03 & 67.15 & 80.25 & 81.11 \\
\hline 1 & 2 & 2 & 2 & 2 & 6 & 4 \\
\hline & 23.48 & 23.48 & 45.28 & 55.43 & 67.22 & 68.00 \\
\hline 2 & 7 & 7 & 2 & 5 & 8 & 8 \\
\hline & 16.23 & 16.23 & 26.76 & 43.97 & 54.45 & 55.15 \\
\hline 3 & 7 & 7 & 7 & 1 & 4 & 6 \\
\hline & & & 17.51 & 32.25 & 41.43 & 42.05 \\
\hline 4 & 8.736 & 8.736 & 1 & 7 & 0 & 4 \\
\hline & & & 11.98 & 24.27 & 32.13 & 32.68 \\
\hline 5 & 4.967 & 4.967 & 7 & 6 & 9 & 5 \\
\hline & & & & 17.51 & 24.06 & 24.53 \\
\hline 6 & 2.420 & 2.420 & 7.685 & 6 & 8 & 6 \\
\hline & & & & 12.38 & 17.62 & 18.01 \\
\hline 7 & 1.500 & 1.500 & 5.010 & 3 & 5 & 5 \\
\hline & & 750 & 505 & & 12.35 & 12.66 \\
\hline 0 & & 1.150 & 3.505 & 8.421 & 2 & 4 \\
\hline 9 & & & 1.750 & 4.208 & 6.829 & 7.063 \\
\hline 10 & & & & 2.000 & 3.310 & 3.466 \\
\hline 11 & & & & & 2.250 & 2.328 \\
\hline 12 & & & & & & 2.500 \\
\hline $\mathrm{Je}$ & 1.500 & 1.500 & 1.750 & 2.000 & 2.250 & 2.328 \\
\hline
\end{tabular}

From Table 5, it can be seen that the value of $f_{12}$ is $2,328,000$ IDR. This value is formed by adding $Z_{11: 12}$ in Table 4 of 328,000 IDR and $f_{10}$ of 2,000,000 IDR. This means that orders are placed in the 11 th period (December W-3) to fulfill up to the 12th period (December W-4) demand of 3,560 kg. The summary of the number of orders can be seen in Table 6 .

Table 6. Optimum Order Size and Cumulative Variable Cost Ingot ADC12 using the Wagner Whitin Algorithm

\begin{tabular}{|c|c|c|c|c|c|c|c|c|c|c|c|c|}
\hline Period & 1 & 2 & 3 & 4 & 5 & 6 & 7 & 8 & 9 & 10 & 11 & 12 \\
\hline Demand $(\mathrm{Kg})$ & 3,900 & 650 & 0 & 8,930 & 3,130 & 4,173 & 3,000 & 0 & 4,500 & 6,302 & 3,360 & 200 \\
\hline Order Size $(\mathrm{Kg})$ & 3,900 & 650 & 0 & 8,930 & 3,130 & 4,173 & 3,000 & 0 & 4,500 & 6,302 & 3,560 & 0 \\
\hline
\end{tabular}




\begin{tabular}{|c|c|c|c|c|c|c|c|c|c|c|c|c|}
\hline $\begin{array}{c}\text { Cumulative variable cost } \\
(1,000 \text { IDR })\end{array}$ & 250 & 500 & 500 & 750 & 1000 & 1.250 & 1.500 & 1.500 & 1.750 & 2.000 & 2.328 & 2.328 \\
\hline
\end{tabular}

Table 7. Optimum Order Size and Cumulative Variable Cost Ingot ADC12 using Silver Meal Algorithm

\begin{tabular}{|c|c|c|c|c|c|c|c|c|c|c|c|c|}
\hline Periode & 1 & 2 & 3 & 4 & 5 & 6 & 7 & 8 & 9 & 10 & 11 & 12 \\
\hline Demand (Kg) & 3,900 & 650 & 0 & 8,930 & 3,130 & 4,173 & 3,000 & 0 & 4,500 & 6,302 & 3,360 & 200 \\
\hline Order Size (Kg) & 4,550 & 0 & 0 & 8,930 & 3,130 & 4,173 & 3,000 & 0 & 4,500 & 6,302 & 3,560 & 0 \\
\hline $\begin{array}{c}\text { Cumulative variable cost } \\
(1,000 \text { IDR) }\end{array}$ & 504 & 504 & 504 & 754 & 1.004 & 1.254 & 1.504 & 1.504 & 1.754 & 2.004 & 2.332 & 2.332 \\
\hline
\end{tabular}

Based on Table 6, it is known that by applying the Wagner Whitin Algorithm to determine the optimum order size, the Ingot ADC-12 order frequency is 9 times and the total variable cost of inventory is 2,328,000 IDR.

\subsection{Order Size Determination using The Silver- Meal Algorithm}

The order size evaluation table can be seen in Table 7 . In the 3rd period in Table 6, the lowest value of $\mathrm{TRC}(\mathrm{T}) / \mathrm{T}$ occurred at the value of 168 , so the demands of the 1 st period to $3 \mathrm{rd}$ period were combined and order are placed in period 1 (Oct W-1) of $4550 \mathrm{~kg}$. Furthermore, the same evaluation is carried out for the rest of the periods.

Table 8. The Average Inventory Cost Calculation

\begin{tabular}{|c|c|c|c|c|c|c|}
\hline 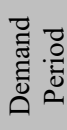 & 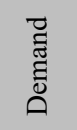 & 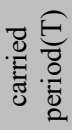 & 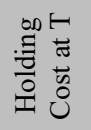 & 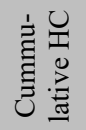 & $\sum_{\frac{\pi}{0}}^{\tilde{\pi}} \dot{0}$ & 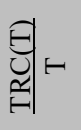 \\
\hline 1 & 3.900 & 1 & - & - & 250 & 250 \\
\hline 2 & 650 & 2 & 254 & 254 & 504 & 252 \\
\hline 3 & - & 3 & - & 254 & 504 & 168 \\
\hline \multirow[t]{4}{*}{4} & 8.930 & 4 & 10.448 & 10.702 & 10.952 & 2.738 \\
\hline & . & . & . & . & - & \\
\hline & . & . & . & . & . & . \\
\hline & . & . & . & . & . & . \\
\hline 11 & 3.360 & 1 & & & 250 & 250 \\
\hline 12 & 200 & 2 & 78 & 78 & 328 & 164 \\
\hline
\end{tabular}

From the calculation of the average variable costs in Table 7, a procurement table is arranged to shows the order placement and order size of the raw materials. The procurement table and cumulative variable cost of inventory using the Silver-Meal Algorithm can be seen in Table 8 .

Based on Table 8, it is shown that by applying the Silver-Meal Algorithm the total variable cost of Ingot ADC-12 inventory is $2,332,000$ IDR with 8 times order frequency.

\section{Result and Discussion}

After calculating the order size using the two proposed methods, namely the Wagner Whitin (WW) and the
Silver-Meal (SM) Algorithm, the inventory cost incurred can be compared as shown in Table 9.

In terms of inventory variable costs (ordering costs and holding costs) that affect the number of inventory costs, the proposed method, the Wagner-Whitin and SilverMeal Algorithm results in savings of 18,403,650 IDR and $18,403,150$ IDR compared to the existing variable costs or equal to $88.8 \%$.

Tabel 9. Comparison of Variable Costs of Inventory Existing Condition and Proposed Method

\begin{tabular}{|c|c|c|c|}
\hline & Existing (IDR) & WW (IDR) & SM (IDR) \\
\hline $\begin{array}{c}\text { Variable } \\
\text { Cost }\end{array}$ & $20,731,180$ & $2,328,000$ & $2,331,500$ \\
\hline $\begin{array}{c}\text { Saving } \\
\text { (IDR) }\end{array}$ & 0 & $18,403,650$ & $18,400,150$ \\
\hline $\begin{array}{c}\text { Saving } \\
(\%)\end{array}$ & $0 \%$ & $88,8 \%$ & $88,8 \%$ \\
\hline
\end{tabular}

Table 10. Comparison of Total Costs of Inventory Existing Condition and Proposed Method

\begin{tabular}{|c|c|c|c|}
\hline & Existing (IDR) & WW (IDR) & SM (IDR) \\
\hline $\begin{array}{c}\text { Total } \\
\text { Cost }\end{array}$ & $1,012,501,650$ & $994,098,000$ & $994,101,500$ \\
\hline $\begin{array}{c}\text { Saving } \\
\text { (IDR) }\end{array}$ & 0 & $18,403,650$ & $18,400,150$ \\
\hline $\begin{array}{c}\text { Saving } \\
(\%)\end{array}$ & $0 \%$ & $1.8176 \%$ & $1.8173 \%$ \\
\hline
\end{tabular}

In terms of the total cost of inventory which includes the purchase cost as a fixed cost of inventory, the WagnerWhitin and Silver-Meal Algorithm as the proposed method results in a savings of $18,403,650$ IDR and $18,400,150$ IDR or managed to save $1.8 \%$ of the total cost of existing inventory as shown in Table 10.

From these results, the proposed method of the WagnerWhitin Algorithm is accepted and can be used as a reference for PT XYZ in planning and controlling their raw material inventories in the next period. And it can be concluded that the optimal order frequency for Ingot ADC-12 from October to December 2018 is nine times to save $1.8 \%$ of the total existing inventory costs.

\section{References}

[1] S. Samak-Kulkarni and N. Rajhans, "Determination of optimum inventory model for minimizing total inventory cost," Procedia Engineering, vol. 51, pp. 803-809, (2013). 
[2] V. Gaspersz, Production planning and inventory control. Jakarta: PT Gramedia Pustaka Utama, (2009).

[3] S. Asmal, I. Setiawan, N. Ikasari, and Y. Adriani, "Inventories Analysis of Animal Feed Raw Materials by Using the Silver Meal Method and Wagner within Algorithm (Case Study of PT. XYZ Makassar)," in IOP Conference Series: Materials Science and Engineering, (2020), p. 012063.

[4] G. Dobson and C. A. Yano, "Cyclic scheduling to minimize inventory in a batch flow line," European journal of operational research, vol. 75, pp. 441-461, (1994).

[5] M. Ji, J. Fang, W. Zhang, L. Liao, T. Cheng, and Y. Tan, "Logistics scheduling to minimize the sum of total weighted inventory cost and transport cost," Computers \& industrial engineering, vol. 120, pp. 206-215, (2018).

[6] B. Li, Q. Ji, and A. Arreola-Risa, "Optimizing a production-inventory system under a cost target," Computers \& Operations Research, vol. 123, p. 105015, (2020).

[7] V. Pando, L. A. San-José, and J. Sicilia, "A new approach to maximize the profit/cost ratio in a stock-dependent demand inventory model," Computers \& Operations Research, vol. 120, p. 104940, (2020).

[8] H. Sarper and N. I. Jaksic, "Simulation of the stochastic one-dimensional cutting stock problem to minimize the total inventory cost," Procedia Manufacturing, vol. 38, pp. 916-923, (2019). 